\title{
How the Defeated Grieve: Philosophy and Memory
}

\author{
Wetzel J* \\ Department of Philosophy, Villanova University, USA
}

*Corresponding author: James Wetzel, Department of Philosophy Villanova University 800 Lancaster Avenue Villanova, PA 19085 USA, Tel: 610-519-4709; Email: james.wetzel@ villanova.edu

\section{Conceptual Paper}

Volume 3 Special Issue 1

Received Date: December 14, 2020

Published Date: December 31, 2020

DOI: $10.23880 /$ phij-16000S1-007

\section{Abstract}

There is a peculiarly philosophical use of memory that is not primarily about the retrieval of information. The aim of this essay is to evoke this memory. The evocation takes two forms: a reading of Virgil's great character, Dido, who wants to be able to distinguish grieving from feeling defeated, and a tribute to the martyred Boethius, a late Roman philosopher who sees in his unjust treatment a reminder not to be unjust. If philosophical memory has practical value, it is not that it makes our lives easier; it is that it keeps us from becoming the people we don't want to be.

Keyword: Philosophy; Memory; Virgil; Boethius; Wittgenstein

I want to begin with an image. It is really a staging of images. Enter Dido. She is a character in Virgil's Aeneid, an epic about the roots of ancient Roman power. ${ }^{1}$ She falls in love, madly as it turns out, with Aeneas, who is destined to become the father-figure of imperial Rome. He doesn't start out that way. Aeneas and Dido are both reluctant leaders of refugee peoples. Dido was once married to Sychaeus, the richest man in Phoenician Tyre. Her brother, Pygmalion, a tyrant king, murders Sychaeus in a secret and cowardly way. The ghost of Sychaeus haunts Dido's dreams, informs her of her brother's treachery, and urges her to flee her homeland. She does, but not without taking all the freedom loving Tyreans with her and, for good measure, the sum of her brother's wealth. When Aeneas and his cohort of warweary Trojans wash up on the shores of Libya, he makes his supplications to Dido, now a Carthaginian queen and never again any man's consort (her vow to her husband's ashes). She proves remarkably generous hearted to the hapless warrior, who lost his wife to the confusion of war and hastily had to carry his father out of a burning city on his back. Venus, the goddess of desire, tells her son, Cupid, to take on

1 P. Vergili Maronis Opera, ed. R.A.B. Mynors, Oxford Classical Texts (Oxford, 1969). the form of Ascanius, the young son of Aeneas, and sit on Dido's lap: think of this as the temptation of a new family and, even more radically, a normal life. Later Juno, the goddess of marriage, will use a black rain of hail to drive Aeneas and Dido into the same cave during a hunting expedition. Dido emerges thinking that she is married to Aeneas and done with ashes. Aeneas thinks otherwise.

Imagine that you have made an oath to the memory of a person you once loved in life, a partner of some sortcompetent, kind, caring, and rich-but now only a ghostly absence. You resolve not to seek a look-alike to ease your loss; there will be no slipping back for you into an old and, in any case, not-so-invulnerable security. You live now for those you call your own, for your people, and you will stay wide-eyed and determined in the face of the lies that human beings constantly tell one another when they crave power over others or try to ignore those who do. But then the day comes when an Aeneas, as broken and as capable as you are, knocks at the door of your sanctuary kingdom and invites you to let down your guard. Perhaps his experience of caring for a refugee people is not so different from your own. There is space for love between the two of you, space for you to inhabit and not simply to protect. As it turns out, however, 


\section{Philosophy International Journal}

the gods that drive Aeneas into his dark future want him to perfect his power over others, not abandon this power for the murkiness of ordinary love. They urge him, through the voice of his dead father, to seek a better empire, a faultless Troy, a Rome, and to practice Roman arts (Aeneid 9.852853): "enforce the peace, spare the defeated, battle down the proud." The boy Ascanius, a stand-in for a future Caesar, will be getting anything but a sentimental education.

When Dido realizes that Aeneas is wed to the familiar game of empire and not to her, she gives up on trying to change his mind, much less his heart. He has his sense of inexorable fate; she has her sense of unmasterable fortune. So be it. She at least hopes to learn something from her side of the impossible. Here are Dido's pregnant words to Anna, who misses the magnitude of her sister's inner struggle (Aeneid 4.433-434):

I seek time's void, the space of requiem for fury, Until my fortune teaches me, defeated [victam], how to grieve.

Dido wants Aeneas to stick around for the lesson. This is her last request as his "wretched lover" (4.429). We need to ask ourselves: why would she want this? He is the very symbol of her defeat, indeed its constant reminder. While he remains, she continues to suffer recurrent nightmares about being savagely hunted down and then losing touch with her people along an endless and lonesome desert road (Aeneid 4.465-468). The cynical possibilities of her state of mind are easy enough to envision. Perhaps she secretly hopes to manipulate her way back into Aeneas's affections through some combination of guilt and seduction, or perhaps she will settle for having his child, an ersatz Aeneas, if only she can get Aeneas back into that cave. The deeper possibility-the one I will call "philosophical"-is what Virgil intimates, rather than announces, through his compelling anti-hero. Dido has some sense that grief is not, after all, a form of defeat and that she will need to know in her own time what the difference amounts to. For now, there is her fury-and her despair.

The philosopher Ludwig Wittgenstein, himself a study in philosophical piety, tells us that "the work of the philosopher consists in assembling memories for a particular purpose." Not just any memories, of course, and not just for any purpose. The aim is clarity-complete clarity, Wittgenstein will insist-and the memories are of how we have come to share language with one another. (In the context of this kind of assemblage, it turns out that there isn't a whole lot of difference between remembering and imagining.) Admittedly

2 Philosophical Investigations, Fourth Edition, ed. P.M.S. Hacker and Joachim Schulte (Blackwell Publishing, 2009), §127. (I have modified the translation.) this may seem too anemic a conception of philosophical work, given the robust labor of human love that is required in this world of ours. But consider, for instance, what a marvel it is to share with others a concept of time. Saint AugustineWittgenstein's favorite saint-famously says this about his own grip on the concept: "What then is time? If no one asks, I know; if I want to explain time to someone asking, I don't know." ${ }^{3}$ Wittgenstein comments: "Something that one knows when nobody asks one, but no longer knows when one is asked to explain it, is something that has to be called to mind. And it is obviously something which, for some reason, it is difficult to call to mind." ${ }^{\prime 4}$

I follow Wittgenstein in thinking that philosophy is not a science, not a preparation for science, not much of any kind of explanatory endeavor. "The name," Wittgenstein suggests, "might be given to what is possible before all new discoveries and inventions." ${ }^{5}$ This is not a conception of philosophy that is without practical consequence. It makes a difference whether I settle into a firmament of loss and remain fixed there, or whether I find myself still open to new discoveries and inventions and harboring at least a modest sense of wonder. The self that is prior to-or perhaps beyond-all new discoveries and inventions is less like a buried treasure than a beauty hidden in plain view. But it is not the job of philosophy to prove to me that I am this self, or that you are: "philosophy just puts everything before us, and neither explains nor deduces anything."

One last illustration. This one is not fictitious, but it has fictional elements. Boethius, the adopted son of a powerful Roman senator, finds himself at the end of his life in a jail cell in Pavia, where he awaits execution (death by bludgeoning). He is a learned man, one of the few of his time who is skilled enough to translate Plato and Aristotle into Latin and supply a unifying commentary. Until recently he has been of the view that philosophy is a political art, able when practiced well to turn violent barbarians into luminous philosopher-kings. That last bit is not going so well for him, however. While serving as a high-placed adviser in the court of Theodoric, the military muscle of the Western empire, Boethius gets accused of seditiously defending a Roman senator whose loyalties have been deemed to lie in the East, with emperor Justinian, and not with the Ostrogothic king in Rome. The political intrigue is pretty thick here. Suffice it to say that Boethius ends up a victim of power politics.

But this is not what he would have us ultimately believe.

3 Augustine, Confessions, Introduction and Text, ed. James J. O'Donnell (Clarendon Press, 1992), conf. 11.14.17.

4 PI $§ 89$.

5 PI $§ 126$.

6 PI $§ 126$. 


\section{Philosophy International Journal}

While imprisoned, Boethius manages by some miracle to compose a work, from start to finish, that has come to be known as The Consolation of Philosophy. It is a treatise on how the defeated learn to grieve. Book one begins with the image of a bested Boethius, the self-portrait of fortune's martyr. ${ }^{7}$ It is of someone convinced that he has been defeated by bad men and worse luck. "Philosophia" soon enters the scene-or philosophy, personified as a regal woman-and she tries to bring Boethius, here a self-pitying sack of aging flesh, back to his senses. She is, of course, already a part of him; she is his estranged memory of philosophy. But he finds it hard to call her back to mind.

And no wonder. Pious recollection will do nothing to change his circumstances. Boethius will live out the short remainder of his life in a cell, he will die by the hands of men who, but for their ignorance, would have been his friends, and he will die not knowing the fate of the beloved family he leaves behind. But even in the thick of disconsolation, he cannot help but remember this: that he is the sort of self who prefers a hard life to an unjust one. However hard things get, he will not ultimately choose to become a Theodoric in order to escape having to live under a Theodoric's rule. The cost is too high. But why is all this comparative valuation being cast as memory? In short: because of its proximity to selfknowledge.

I don't mean to suggest that the art of philosophical memory is, at bottom, faith in the self and its goodness. I have no vision of everyone one day waking up together, remembering the ties that bind us to a shared responsibility, and falling out of fixation with the political games that exult one human being at the expense of another and make wreckage out of our collective place in nature. To be clear, it is not quite that I cannot imagine this scene (let's call it "The Last Judgment"); I just cannot imagine the timing. Neither could Boethius.

7 Boethius, De consolatione philosophiae, Loeb Classical Library (Harvard, 1973), prologue and section one.
In book three of the Consolation-at the center point of self-healing-the philosopher in Boethius convinces the prisoner that he is forever at one with the being for whom it is good simply to exist (and who cannot but exist). If that heady thought is true, then Boethius is a prisoner only to his self-imprisonment, and even self-imprisonment, as a condition of existence, may not be so bad. Tellingly, Boethius does not end book three's alchemy with the perfection of the God-soul relationship. He goes on to recount his own version of the Orpheus and Eurydice myth. ${ }^{8}$

In the version known to him, probably through Ovid, Orpheus is a poet and musician whose artfulness rivals that of Apollo himself; Eurydice is his bride-to-be. On the day of their wedding, Eurydice suffers a serpent's bite and is plunged precipitously into the underworld. Orpheus follows her there, in defiance of the traditional separation between the living and the dead, and petitions Pluto, Lord of Darkness, to release his bride. Pluto agrees-Orphic music is indeed hard to resist-but on one condition: Orpheus is never to look back to see whether Eurydice is following him into the light. In Boethius's reframing of this myth, the underworld is primarily a place where sins are punished (i.e., it is looking more like Christian hell) and Eurydice is not just a beloved woman. She is also, as her name implies, the ideal of justice itself (in Greek her name means, "wideranging justice"). When the Orphic Boethius looks back to see whether his philosophical faith still has a hold on Eurydice, he frames justice against a backdrop of retribution, against the torments of hell, and loses both the woman and the ideal.

I used to think that no good could ever come of a look back into places darkened by the fear of loss. But now I think that Dido, even in her madness, may have had some wisdom. We don't always grasp out of fear of loss; we also reach to reassure, as in times when the ideals of love and justice are not enough. It is philosophy that puts us in mind of the difference.

8 Consolatio, book three, section twelve. 